\title{
Partai Keadilan Sejahtera di Tengah Pusaran Tren Penurunan Anggota Partai: Bagaimana Cara Mereka Bertahan?
}

\author{
Sri Melan Sedriyani ${ }^{1}$ \\ Diserahkan: 8 Februari 2021 | Diterima: 19 Juli 2021 | Diterbitkan: 30 Juli 2021
}

\begin{abstract}
Abstrak
Studi ini merupakan penelitian kualitatif yang berusaha menjawab pertanyaan, "Bagaimana keanggotaan di tubuh Partai Keadilan Sejahtera (PKS) di tengah tren penurunan anggota partai politik?” dengan berasumsi bahwa telah terjadi penurunan anggota di tubuh PKS. Dengan dikerangkai menggunakan analisis Bizen dan Poguntike, penelitian ini menemukan bahwa PKS juga mengalami penurunan anggota formal partai politik yang disebabkan oleh pergeseran bentuk partai yang mengarah pada jenis catch all. Namun, penggunaan organisasi kolateral dalam mepertahankan kinerja PKS bukan merupakan strategi pertahanan diri melainkan merupakan strategi afiliasi yang dibangun PKS, bahkan sebelum terjadi penurunan anggota.
\end{abstract}

Kata kunci: PKS; Penurunan anggota; Kolateral

\footnotetext{
1 Penulis adalah mahasiswa program sarjana Departemen Politik dan Pemerintahan, Universitas Gadjah Mada.
} 


\section{PENDAHULUAN}

Pada prinsipnya, pembicaraan mengenai keanggotaan partai berkenaan dengan bagaimana keterikatan antara kekuatan partai di akar rumput serta seberapa jauh signifikansi keanggotaan di era modern. Dalam beberapa dekade terakhir, jumlah anggota partai politik di Eropa mengalami penurunan yang cukup signifikan tiap tahunnya. Bukan hanya itu, dalam hal partisipasi politik tradisional juga kerap menurun. Bizen dan Poguntike (2014) menuliskan bahwa pada awal abad ke-21, rasio rata-rata keanggotaan partai terhadap pemilih di seluruh negara demokrasi (lama dan baru) Eropa berkisar pada angka 5\%, sedangkan pada tahun 1980, rata-rata hampir 10\% dari pemilih di negara demokrasi lama memiliki afiliasi dengan partai politik. Atau, apabila menarik mundur ke tahun 1960-an, ratarata rasio anggota partai menyentuh hampir di angka 15\%. Namun, data ini tidak terlalu menangkap fenomena di Belanda antara tahun 2000-2009: data menunjukkan bahwa terjadi penurunan margin dari 2,51\% pada tahun 2000 ke angka 2,48\% pada tahun 2009. Di sisi lain, data tahun 2004 menunjukkan adanya peningkatan ke angka 2,56\% (Kölln, 2016).

Mengerucut pada realitas yang terjadi di Indonesia, penelitian mengenai penurunan jumlah anggota partai 
politik terbilang sangat langka. Dengan demikian, fenomena ini tidak mudah dilacak oleh masyarakat umum maupun ilmuan politik. Hal ini sangat mungkin disebabkan terbatasnya akses data internal partai politik. Namun, senada dengan nuansa rasa memiliki sebuah partai politik, fenomena rendahnya PartyID di Indonesia bisa menjadi pintu awal memahami penurunan anggota partai politik. Diketahui, tingkat Party-ID di Indonesia dari tahun ke tahun terus mengalami penurunan. Pada tahun 2014, 2017, dan 2021 secara berurutan, Party ID Indonesia adalah 14,3; 11,7; dan 6,8 persen (Febriyanty, Yenny, Ghafur, Jamaludin, \& Ariyanto, 2019; Reinjani, 2018; Salabi, 2021). Lebih spesifik pada jumlah anggota, pada tahun 2019 jumlah anggota parpol hanya 4,9\% dari jumlah pemilih (Febriyanty, Yenny, Ghafur, Jamaludin, \& Ariyanto, 2019). Mengenai PKS, sajian jumlah anggota sementara ini masih terbatas pada jumlah anggota pada tahun 1998 (masa pembentukan awal PKS) yang mengalami kenaikan hingga tahun 2004 (Machmudi, 2006; Rahmat, 2008). Sementara itu, update data hampir tidak ditemukan dalam kajian bertahun-tahun kemudian.

Di tengah tren penurunan anggota yang demikian adanya, artikel ini berusaha mengulas terkait 
keanggotaan Partai Keadilan Sejahtera (PKS). Pembicaraan mengenai PKS selalu menarik dalam demokrasi di Indonesia. PKS memiliki citra yang cukup teguh dalam hal ideologi partai, ia dikenal sebagai partai yang memegang teguh prinsip gerakan revivalis Islam di tengah sistem demokrasi yang ada (Munabari, 2017; Permata, 2008; Machmudi, 2006). Namun, beberapa studi menunjukkan bahwa PKS seiring berjalannya waktu mulai melakukan adaptasi dan memoderasi dirinya serta mampu menerima sistem demokrasi berbasis pembagian kekuasaan (Hasan, 2009; Permata, 2008; Tomsa, 2012; Tanuwidjaya, 2012; Buehler, 2012). Lalu, apakah hal tersebut berdampak pada penurunan anggota PKS? Tulisan ini menemukan bahwasanya semakin mengarah ke arah catch-all, PKS mengalami penurunan anggota partai. Namun, hal tersebut tidak berimbas banyak pada prospek suara partai. Karena, data menunjukkan bahwa PKS mengalami keberhasilan yang cukup tinggi dalam perolehan suara di beberapa tahun ini.

Untuk memperoleh jawaban atas asumsi dan pertanyaan mengenai jumlah anggota dan mekanisme bertahan di PKS, tulisan ini menggunakan meode pengambilan data melalui literatur dan telewicara. Data hasil telewicara dilengkapi dengan pengidentifikasian 
melalui berita dan riset-riset yang berkaitan. Kemudian, data dianalisis menggunakan metode kualitatif. Metode ini digunakan karena tulisan ini tidak sedang mencari rasio penurunan anggota partai terhadap pemilih (M/E Ratio), tetapi lebih pada pencarian linkage yang terbangun di tengah penurunan anggota PKS. Dengan demikian, penelitian ini menjadijauh lebih komprehensif apabila dijalaskan melalui metode kualitatif.

Sebagai basis analisis, tulisan ini merujuk pada artikel jurnal "The Decline of Membership-based Politics" yang ditulis oleh Ingrid van Biezen dan Thomas Poguntke (2014). Konsepsi tersebut pada prinsipnya memberi garis besar bahwa perubahan bentuk partai akan membuat partai mengalami penurunan jumlah anggota sehingga partai memanfaatkan linkage dengan organisasi kolateral untuk menjaga stabilitas suara partai di Pemilu. Oleh karena itu, data periodik penurunan anggota partai PKS dari tahun 1998-2021 yang digali dalam tulisan ini disandingkan dengan analisis perubahan karakteristik partai PKS dan ditutup dengan anslisis linkage yang terjalin antara PKS dengan salah satu organisasi ke-Islam-an di Indonesia. 


\section{BASIS DAN IDEOLOGI: BAGAIMANA DINAMIKA KEANGGOTAAN MEMPENGARUHI CORAK IDEOLOGI PKS?}

Kajian mengenai Partai Keadilan Sejahtera cukup mudah ditemui dalam berbagai literatur partai politik di Indonesia. Baik diulas dalam suatu artikel jurnal maupun buku tersendiri, ataupun terselip dalam beberapa pembahasan terkait. Topik yang acap kali diperbincangkan berkenaan dengan ideologi partai, keterkaitan PKS dengan gerakan Islam Internasional, organisasi sayap partai di kampus, faksionalisme di tubuh partai, serta beberapa topik lain yang mengaitkan posisi keberpihakan PKS dengan demokrasi di Indonesia.

Salah satu bacaan yang cukup "inti" dan dijadikan rujukan komprehensif dalam pembahasan partai PKS adalah sebuah buku berjudul "Islamising Indonesia: the Rise of Jemaah Tarbiyah an The Prospereous Justice Party (PKS)" (Machmudi, 2006). Buku tersebut secara garis besar mengupas keterkaitan antara Partai Keadilan Sejahtera (PKS) dengan Jemaah Tarbiyah selaku basis anggota partai dan beberapa organisasi di kampus sebagai bagian dari organisasi sayap partai PKS. Dengan membagi santri menjadi tiga kategori neo-santri, yakni konvergen, radikal, dan global, Yon Machmudi menuturkan bahwa aktivis PKS yang 
kebanyakan berasal dari Jemaah Tarbiyah, masuk adalah kategori santri global (2006). Keterkaitan PKS dengan Jemaah Tarbiyah juga diulas oleh Permata (2008) melalui disertasinya yang berjudul "Islamist Party and Democratic Participation: Prosperous Justice Party (PKS) in Indonesia 1998-2006”. Baginya, Gerakan Tarbiyah merupakan agenda politik bottom-up gradual yang memulai langkahnya dengan mengislamkan individu, keluarga, masyarakat, dan politik. Oleh karena itu, komunitas Tarbiyah membentuk partai bernama PK yang kemudian menjadi PKS.

Topik selanjutnya ialah pergeseran perilaku PKS ke arah yang lebih moderat. Banyak ilmuan sosial yang membicarakan ini. Salah satunya, Dirk Tomsa (2012) melalui artikel jurnalnya, "Moderating Islamism in Indonesia: Tracing Patterns of Party Change in the Prosperous Justice Party". Tulisan tersebut secara garis besar berargumen bahwa PKS memang menjadi lebih moderat, tetapi kesuksesan yang diraihnya pasca pemilu membuat tantangan serius terhadap koherensi organisasi partai tersebut. Yakni, PKS sebagai partai yang solid harus menghadapi keretakan antara kelompok pragmatis dan idealis. Ada pula artikel jurnal " $P K S$ in post-Reformasi Indonesia; Catching the catch-all and moderation wave" (Tanuwidjaya, 2012). Kajian tersebut 
berargumen bahwa strategi moderasi yang dilakukan oleh PKS membuatnya berada dalam persaingan sulit dengan partai-partai besar yang mapan untuk pemilih median. Dengan bergesernya PKS menjadi partai catch-all, itu membuat sistem kepartaian Indonesia hampir didominasi catch-all party. Selain moderasi yang berlaku di ranah eksternal partai tersebut, ulasan moderasi perilaku politik internal PKS telah dilakukan oleh Buehler (2012). Ia berpendapat bahwa faktor sosiokultural di dalam partai PKS telah berhasil membentuk dinamika kekuasaan internal partai menjadi lebih moderat dalam perilaku politiknya, baik di tingkat politik lokal maupun nasional.

Selain dua topik di atas, pembahasan faksionalisme di tubuh PKSjuga menarik perhatian berbagai ilmuan sosial. Jurnal berjudul "Changing Patterns of Factionalism in Indonesia: From Principle to Patronage" disebutkan bahwa faksionalisme biasanya dicirikan dengan dasar klientilisme, dibanding pencerminan dari pembilahan sosial, perbedaan ideologi, atau afiliasi regional. Namun, PKS menunjukkan suatu peristiwa anomali, sisa-sisa faksionalisme yang bersifat programatik pada dasarnya hanya dapat ditemukan di tubuh PKS (Fionna \& Tomsa, 2020). Selain itu, ada pula artikel jurnal berjudul "The Emergence of Gerakan Arah Baru (Garbi) 
and Factionalism in Partai Keadilan Sejahtera (PKS)" (Priohutomo, dkk., 2019). Kajian Boucek (2009) secara terperinci mengupas faksionalisme di PKS melalui teori yang ia tawarkan, yakni menggunakan teori tiga wajah faksionalisme; kooperatif, kompetitif, dan degeneratif. Boucek (2009) melihat bahwa faksionalisasi yang terjadi dalam tubuh PKS berkenaan dengan Garbi cenderung menunjukkan arah kooperatif menuju kompetitif. Selanjutnya, studi tersebut juga berpendapat bahwa faksionalisasi di tubuh PKS dipengaruhi oleh nilai-nilai doktrinal yang mengakar di antara kader-kadernya. PKS dapat meredam dampak parah dari kecenderungan berfaksi yang kompetitif atau bahkan degenerative (Boucek, 2009).

Terakhir, topik yang sering dikupas dalam kajian mengenai PKS ialah ihwal organisasi dan keanggotaan. Tulisan Kikue Hamayotsu (2011) misalnya, menjelaskan keberhasilan PKS dalam memobilisasi dan merekrut pemuda Muslim. Baginya, hal tersebut disebabkan oleh dua faktor, yaitu 1) rekrutmen dan promosi kader berdasarkan pernikahan. Sebab, PKS menawarkan kepada pemuda terkait ambisi, keimanan, dan peluang karir politik, serta menjadikan hal tersebut sebagai alasan komitmen pada kepentingan kolektif partai; 2) waktu ekspansi organisasi yang bertepatan dengan 
peningkatan cepat kantor negara dilevellokal. Kemudian, argumen menarik juga disampaikan oleh Nurdin (2011) yang menemukan strategi pola rekrutmen dan ekspansi yang dilakukan oleh PKS dalam mencetak kader-kader baru. Cara tersebut yakni dengan mendorong kaderkader PKS untuk memiliki banyak anak. Selanjutnya, skripsi yang ditulis oleh Fatra Yudha Paratama (2019) dengan judul "Pola Relasi KAMMI Sebagai Organisasi Kolateral PKS Pasca Konflik dan Fahri Hamzah.” KAMMI (Kesatuan Aksi Mahasiswa Muslim Indonesia) diposisikan sebagai organisasi kolateral/organisasi sayap partai dari PKS. Namun, pola relasi yang terjalin bersifat independen serta pengaruh KAMMI terhadap PKS bersifat variatif pada setiap isu dan individu.

Di antara banyaknya studi yang melibatkan diri pada telaah organisasi sayap partai, tulisan ini menyoroti satu artikel yang cukup memiliki kedekatan ide dengan kajian ini. Tulisan tersebut berjudul "Peran Organisasi Sayap Partai Politik (OSP) dalam Mencegah Kemerosotan Keanggotaan Partai Politik di Indonesia" (Febriyanty, Yenny, Ghafur, Jamaludin, \& Ariyanto, 2019). Samasama menyoroti kemerosotan anggota partai politik, tulisan tersebut berargumen bahwa fenomena penurunan jumlah anggota di Indonesia merupakan akibat dari menurunnya kepercayaan masyarakat pada 
partai politik dan sistem politik secara umum. Namun, artikel tersebut hanya melampirkan "betapa kecilnya" jumlah anggota partai dibanding jumlah pemilih pada tahun 2019 dan tidak menampilkan data penurunan jumlah anggota partai secara umum dari tahun ke tahun.

Berdasar pada pemaparan hasil kajian yang dominan dilakukan terhadap PKS, tulisan ini berusaha mencari celah dan mengisinya dengan kebaruan penelitian. Dari berbagai literatur mengenai PKS, jarang-bahkan tidak ada-yang membahas perkara penurunan anggota di partai tersebut. Data jumlah anggota PKS dalam berbagai literatur secara terpisah, tidak ada yang menjadikannya sebagai bahan analisis mendalam (Machmudi, 2006; Rahmat, 2008). Padahal, jika disatukan data dari awal berdiri hingga kini, data periodik PKS sangat menarik untuk ditelaah. Tulisan ini menemukan bahwa sejak tahun berdirinya pada 1998, PKS mencapai puncak kenaikan anggota pada tahun 2004 di angka 394.190 orang dan terus menurun ke jumlah 320.000 orang pada tahun 2014 dan 300.158 orang pada tahun 2020. Oleh sebab itulah, tulisan ini melacak latar belakang di balik penurunan anggota yang beranjak pada data terkait. 


\section{PENURUNAN JUMLAH ANGGOTA DAN MEKANISME BERTAHAN: SEBUAH LANDASAN TEORITIS}

Penurunan basis anggota yang hampir terjadi di seluruh partai disebabkan oleh adanya penyesuaian ideologi dan organisasi partai terhadap faktor eksternal yang ada (Biezen \& Poguntke, 2014). Pertama, adanya inovasi teknologi dan modernisasi ekonomi menggeser pola sosial ekonomi tradisional yang berbasis "komune" atau tata hidup bersama. Oleh karena itu, identitas kolektivitas antarkelas sosial (basis partai massa) menurun. Selain itu, organisasi keagamaan tidak bisa diandalkan dalam kerja sama karena jumlah pengikutnya juga menurun-utamanya karena tren sekularisme. Kedua, penurunan basis juga disebabkan oleh adanya perubahan sumber pendapatan partai. Yakni, adanya fenomena modernisasi komunikasi massa sehingga tidak lagi bergantung pada pendanaan publik. Kedua faktor tersebut menyebabkan mekanisme top-down dominan, pendekatan partai yang catch-all, dan berujung pada penyingkiran model tradisional partai massa.

Perubahan pendanaan menurunkan keterikatan anggota dan relasi partai dengan publik sedangkan akses langsung elit partai terhadap media komunikasi membuat peran pegiat di tingkat akar rumput 
tergantikan oleh petinggi partai. Perubahan bentuk partai juga terjadi dalam tubuh PKS secara tidak langsung. Dilihat dari ideologinya, meski hadir dari golongan Islam garis kanan, PKS dinilai tidak terlalu dari spektrum penerimaan terhadap Pancasila. Yakni, berada pada angka 5,53 dari pengukuran 1-10 (Aspinall, Fossati, Muhtadi, \& Wrburton, 2018). Keterbukaan ini menimbulkan dua sisi pemahaman bahwa mungkin anggota PKS telah mengalami pergeseran paradigma, atau mungkin PKS menggeser paradigma untuk mencari keuntungan suara? Jawaban ini menjadi mudah ditentukan apabila menilik fakta bahwa partai politik tidak akan bertahan tanpa dukungan suara dari pemilih, itu sebabnya segala upaya diarahkan untuk mencapai tujuan pencapaian suara tersebut (Poguntke, 2002).

Kemerosotan anggota partai politik sebetulnya juga dapat dilacak seiring perubahan bentuk partai. Bizen dan Poguntike (2014) membayangkan perubahan partai sebagai suatu perkembangan bentuk dari partai berbasis massa yang menekankan pada aspek ideologi, kemudian bergulir menjadi partai catch-all, atau bahkan partai kartel. Partai massa adalah partai dengan pengorganisasian yang paling bagus, karena dalam pelaksanaan organisasinya melibatkan anggota secara aktif. Namun, terjadinya penurunan anggota 
dan ambisi merekrut sebanyak-banyaknya pemilih menjadikan partai berorientasi catch-all. Marina Costa Lobo (2008) memiliki argumen yang cukup menarik mengenai partai massa dan catch-all yang cukup mendasar. Baginya, partai berbasis massa berinvestasi pada mobilisasi individu-individu yang termasuk dalam pembilahan sosial-yangmana ingin diwakili oleh partai, serta adanya aspek ideologi yang muncul di dalamnya. Di sisi lain, dalam tipe partai catch-all, peran pemimpin sangat besar dalam strategi pemilihan mereka. Ia memiliki komponen ideologi yang terdelusi dan berupaya memobilisasi pemilih dari berbagai latar belakang sosial. Dengan demikian, ideologi tidak lagi menjadi penting karena orientasinya bertumpu pada sebanyak-banyaknya jumlah pemilih.

Kemudian, muncul apa yang dikenal sebagai fenomena partai kartel. Secara garis besar, partai kartel adalah fenomena keterkaitan partai dengan negara yang setidaknya meliputi tiga dimensi, yaitu ketergantungan partai terhadap negara, pengelolaan partai yang dilakukan oleh negara, dan penangkapan negara oleh partai politik (Biezen \& Kopecky, 2014). Dalam partai tersebut, anggota partai semakin termarjinalkan dalam organisasi (Biezen \& Poguntke, 2014). Selain itu, terpusatnya pengambilan keputusan di tangan 
elit partai menyebabkan tidak adanya demokrasi intra partai. Keanggotaan partai dalam partai kartel dijadikan sebagai alat validasi dan legitimasi demokrasi partai, daripada menjadi mesin penghubung antara elit partai dan masyarakat luas. Dengan demikian, orientasi partai dewasa ini lebih pada "memohon" suara dibandingkan dengan "mewakili" suara publik. Pada gilirannya, itu berujung pada pergeseran nilai "the vote of belonging" ke nilai "the vote of opinion". Solidaritas anggota partai dalam kondisi tersebut telah bergeser menjadi instrumental dan cenderung lemah.

Salah satu alternatif untuk berdamai dengan fakta bahwa partisipasi publik terhadap partai menurun adalah dengan membangun linkage dengan organisai lain dalam ikatan afiliasi (Hooghe \& Ko "lln, 2018). Organisasi afiliasi partai politik memiliki tiga kondisi kesetaraan yang membuatnya layak mengisi kekosongan peran anggota partai politik. Kondisi kesetaraan pertama, organisasi afiliasi partai memiliki peran dalam menjaga stabilitas dukungan terhadap partai politik meski stabilitas yang dihasilkan oleh anggota partai lebih tinggi dibandingkan stabilitas yang dihasilkan organisasi afiliasi partai. Kondisi kesetaraan kedua adalah kesamaan sikap politik. Kesetaraan yang terjalin antara pendukung loyal dengan anggota partai dalam 
hal ini diraih melalui kesetaraan komitmen dan ideologi atas partai politik. Kemudian, kondisi kesetaraan ketiga ialah kesamaan dalam perilaku politik. Dalam dimensi ini, pendukung loyal dan anggota partai dapat setara dalam hal keaktifan dalam kegiatan partai dan kampanye, juga dalam hal stabilias preferensi partai.

Dalam tulisan ini, organisasi afiliasi yang dilembagakan secara informal oleh partai disebut sebagai organisasi kolateral. Ha tersebut dapat digambarkan sebagai wadah yang memungkinkan partai membentuk "keanggotaan baru" yang terikat secara informal dan berkontribusi dalam proses elektoral. Organisasi kolateral dimaknai sebagai lembaga yang sudah secara tradisional terlembaga, disusun berdasarkan hierarki, dipimpin oleh elit yang stabil, dan mampu menjamin hubungan pertukaran yang stabil dengan partai politik (Biezen \& Poguntke, 2014). Organisasi tersebut memiliki peran sebagai mediator elit partai dengan massa publik, serta menjembatani relasi elit politik dengan aktor kolektif. Secara garis besar, organisasi kolateral dibagi menjadi dua macam (Biezen \& Poguntke, 2014) yakni organisasi sayap, yang memiliki kepentingan tumpang tindih satu sama lain, serta organisasi massa yang independen dari partai politik dan dan memiliki nilai negosiasi yang tinggi. Sebagai contoh, partai dapat 
menjalin relasi dengan serikat buruh dan organisasi keagamaan meski keduanya mengalami penurunan anggota secara signifikan, tetapi masih membuka peluang positif.

\section{PKS DALAM TREN PENURUNAN ANGGOTA PARTAI POLITIK; APAKAH MENGALAMI FENOMENA SERUPA?}

Tren penurunan jumlah anggota partai politik di Eropa dari tahun ke tahun (Biezen \& Poguntke, 2014; Ko "lln , 2016) ternyata juga terjadi dalam tubuh partai PKS di Indonesia. Sebetulnya, data terkait jumlah anggota PKS sangat sulit didapatkan. Setelah dilakukan telewicara dan konfirmasi lebih lanjut dengan Kepala Biro Organisasi Dewan Pimpinan Pusat PKS (Arfian, 2019), data terkait keanggotaan PKS bersifat internal dan tidak dapat dipublikasikan. Namun, tulisan ini berhasil memperoleh angka jumlah anggota PKS yang diunggah di laman SIPOL KPU guna pendaftaran pemilu. Berdasarkan pernyataan Arfian (2019), pada pemilu 2019 PKS melaporkan secara resmi anggotanya berjumlah 300.158 orang. Angka tersebut juga masih dapat berubah karena-menurutnya-ada beberapa yang meminta dihapus keanggotaannya. Menarik mundur pada pemilu 2014, PKS melalui wawancara tersebut 
mengaku telah melaporkan jumlah anggotanya sekitar 320.000 kader.

\section{Grafik 1. Jumlah Anggota PKS}

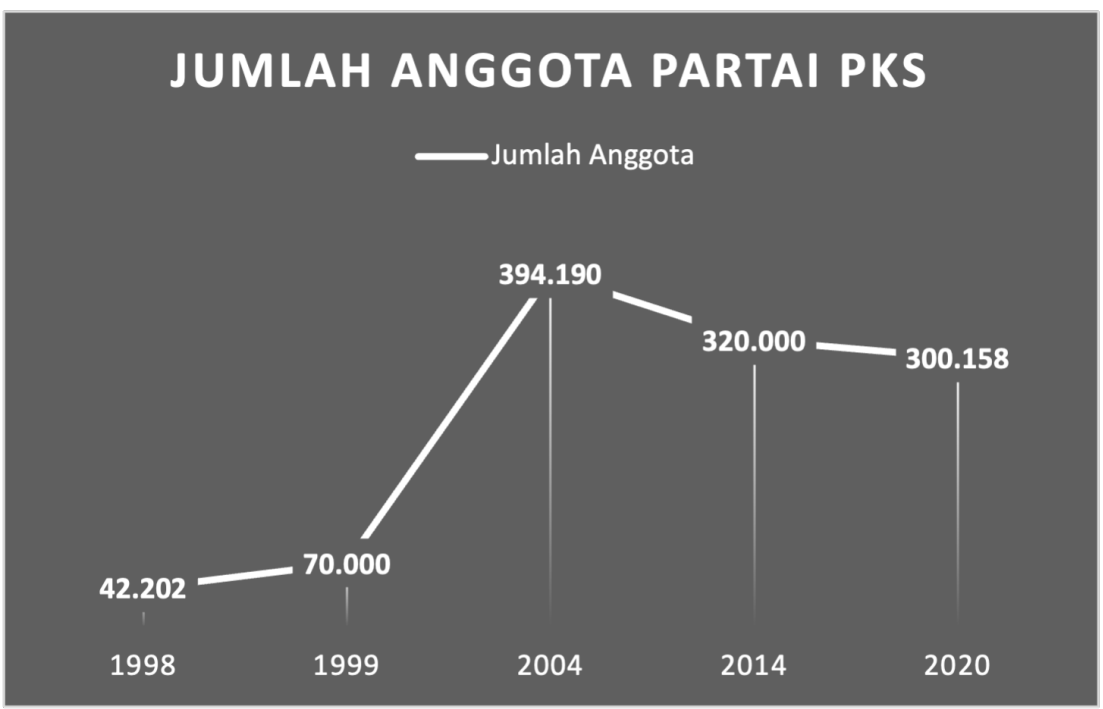

Untuk beberapa tahun sebelumnya, Arfian (2019) mengaku bahwa semenjak awal pendataan anggota PKS tidak dikelola secara ajeg (tetap), selain itu juga menunjukkan bahwa pengelolaan data bergantung pada kepengurusan yang satu dan lainnya sehingga sulit untuk mengetahui informasi mendalam hanya dari satu kepengurusan. Tulisan ini menemukan data jumlah anggota PKS dari tahun 1998, era pemilu 1999 dan 2004 dalam Rahmat (2008) dan Yon Machmudi (2006). Pada tahun awal masa berdirinya di tahun 1998, 
PKS beranggotakan 42.202 orang, tahun 1999 diketahui memiliki anggota sebanyak 70.000 orang, dan naik signifikan pada tahun 2004 menjadi sebanyak 394.190 anggota. Terkait penyebab menurun dan meningkatnya jumlah anggota PKS akan dijelaskan dalam penjelasan selanjutnya.

\section{PKS DAN BENTUK PENYESUAIAN DIRI}

Merosotnya jumlah anggota partai juga dapat disebabkan oleh adanya perubahan bentuk partai dari massa ke catch-all. Seperti diungkapkan oleh Lobo (2008), istilah partai massa merujuk pada partai yang berinvestasi pada mobilisasi individu-individu yang termasuk dalam pembilahan sosial, yangmana kelompok tersebut ingin diwakili oleh partai sehingga ada aspek ideologi yang muncul di dalamnya. Sementara itu, istilah partai catch-all merujuk pada partai dengan peran pemimpin sangat besar dalam strategi pemilihan. Ia memiliki komponen ideologi yang terdelusi dan berupaya memobilisasi pemilih dari berbagai latar belakang sosial. Dengan demikian, ideologi tidak menjadi suatu prioritas dan hanya berorientasi pada sebanyak-banyaknya pemilih. 
Pembicaraan mengenai Partai Keadilan Sejahtera (PKS) selalu tidak dapat dipisahkan dari Partai Keadilan (PK) sebagai bibit pendahulunya. Didirikan menjelang pemilihan tahun 1999, PK hadir dengan misi kampanye purifikasi Islam (Permata, 2008). Secara lebih rinci, PK mempercayai bahwa dengan berbasis pada shari'a, muslim dapat dapat melawan dominasi kekuasaan barat yang berkolaborasi dengan zionis dalam merusak Islam (Hasan, 2009).

Sebagai partai berbasis massa, PK hadir melalui agenda politik bottom-up komunitas Tarbiyah. Dilihat dari aspek historis, setidaknya ada tiga teori yang menerangkan terbantuknya komunitas Tarbiyah yang berujung pada pembentukan PK (Permata, 2008). Pertama, menjelaskan Tarbiyah sebagai gerakan yang diinisiasi oleh aktivis mahasiswa di Masjid Salman Institut Teknologi Bandung (ITB). Saat didirikan pada Mei 1972, Masjid Salman memang membawa misi untuk mengakomodir, memfasilitasi, dan mengorganisir mahasiswa Muslim ke dalam komunitas di kampus. Kedua, kelompok Gerakan Tarbiyah bukan fenomena baru dalam aktivisme di Indonesia tetapi merupakan kelanjutan dari Dewan Dakwah Islamiyah Indonesia. Dalam mamfasilitasi perkembangan gerakan Tarbiyah, peran DDII adalah 1) secara aktif berkontribusi dalam 
pembangunan dan pengembangan masjid dan komunitas Islami di kampus sekular; 2) mendapat pengesahan oleh Kementerian Agama untuk mengorganisir beasiswa ke universitas di Timur Tengah; 3) menerjemahkan dan menerbitkan hasil kerja penulis Timur Tengah, seperti Hassan Al-Banna, Sayyid Qutub, dan Said Hawwa, yangmana buku-buku tersebut menjadi rujukan anggota Tarbiyah. Terakhir, teori ini mempercayai bahwa gerakan Tarbiyah diinisiasi oleh siswa Indonesia yang baru saja kembali dari Timur Tengah pada 1980-an. Target gerakan Tarbiyah adalah pelajar dan mahasiswa melalui jaringan kelompok studi Islami.

Dari sisi ideologis, kelompok Tarbiyah merupakan salah satu kelompok sosial keagamaan yang membawa misi re-Islamisasi sesama Muslim Indonesia, khususnya pemuda dan pelajar, dengan meningkatkan "kualitas" individual dalam hal moralitas dan perilaku (Machmudi, 2006). Mengenai kepercayaan antara Islam dan negara, kelompok ini cenderung percaya bahwa Islam mengandung kedua dimensi dari agama dan negara (al-din wa al-dawlah). Baginya, fungsi negara adalah untuk memastikan dan mempertahankan kelangsungan hidup agama, sementara partai-partai Islam merupakan sarana yang diperlukan untuk membawa perubahan bertahap di negara untuk mengambil sikap yang lebih 
terbuka terhadap Islam. Pada perkembangannya, Jemaah Tarbiyah dan Partai Kadilan adalah satu kesatuan institusi (Machmudi, 2006). Oleh karenanya, PK sudah cukup dikatakan sebagai partai massa karena membawa misi dan ideologi yang jelas berasal dari kelompok Jamaah Tarbiyah.

Hasil pemilu 1999 tidak dapat membawa PK untuk melaju pada pemilu selanjutnya, dan kemudian Komunitas Tarbiyah membentuk partai bernama Partai Keadilan Sejahtera (PKS) di Jakarta 20 April 2002, dan pada April 2003 PK memutuskan untuk merger dengan PKS (Permata, 2008). Namun dalam hal ini, PKS mengganti misi Islamisme-nya ke isu-isu general dan bersemboyan "bersih dan peduli." Bersih merujuk pada agenda kampanye anti-korupsi sebagai image publik dari partai PKS sedangkan "peduli" merujuk pada partisipasi dan memfokuskan diri pada program pelayanan sosial. Aktivis PKS hampir selalu menjadi tim pertama yang hadir di tempat kejadian bencana alam dan selalu hadir beserta identitas kepartaian. Alih-alih sudah moderat sepenuhnya, PKS dalam waktu yang bersamaan masih mempertahankan karakter Islamisnya, seperti berfokus pada politik Muslim Internasional. Contohnya, mengorganisasi demonstrasi penentangan okupasi Israel di Palestina, mempromosikan dukungan 
terhadap warga Palestina, menginisiasi demonstrasi melawan invasi Amerika Serikat kepada Afghanistan dan Iraq (PKS, 2006: 157-159 dalam Permata, 2008). Fenomena ini persis seperti istilah, "partai radikal, dengan kata lain, mungkin belum tentu menjadi lebih moderat secara ideologis, tetapi akan menyesuaikan perilaku mereka sesuai dengan insentif kelembagaan" (Kalyvass, 2000; Share and Mainwaring, 1986: 175 dalam Buehler, 2012).

Wajah pluralis PKS lebih kentara lagi ketika sekitar tahun 2006 dan seterusnya, para pemimpin partai menjadi semakin bertekad untuk mengarahkan PKS ke pusat perhatian dan beberapa tokoh berpengaruh mulai menolak label "Islamisme" serta mengklaim bahwa PKS berhaluan "religuis-nasionalis" (Tomsa, 2012). Penegasan posisi PKS dalam pembukaan diri terhadap ide-ide di luar ideologinya dilakukan ketika menggelar Musyawarah Kerja Nasional (Mukernas) di Bali. "Rekonsiliasi nasional menjadi pintu gerbang bagi semua ide dan harapan ini," tegas Mahfudz, Ketua Badan Perencanaan Partai DPP PKS (Kompas. com, 2008). Lebih lanjut, pada tahun 2010, PKS mulai membuka diri terhadap non-Muslim dan Barat. Namun, PKS tidak moderat sepenuhnya-dalam beberapa isu strategis, ia kembali menampilkan wajah eksklusifnya 
sebagai partai berhaluan Islam (Tomsa, 2012). Meskipun PKS di satu sisi telah berhasil menampilkan diri sebagai partai catch-all, tetapi di sisi yang lain ia tetap mempertahankan wajah Islamisnya sebagai strategi untuk melestarikan dukungan dari kelompok Islam konservatif (Tanuwidjaya, 2012).

PKS belum cukup memenuhi untuk dijuluki sebagai partai kartel. Seperti yang diketahui bersama, prasyarat partai kartel ialah terjalinnya hubungan-bahkan ketergantungan-partai terhadap negara (Biezen \& Kopecky, 2014). PKS merupakan partai yang memiliki posisi yang teguh sebagai "oposisi" dan kerap kali mengkritisi jalannya pemerintahan, khususnya tahun 2019. Meski rekan-rekan partai politik pengusung Prabowo-Sandi di Pilpres 2019 mulai masuk ke dalam kabinet presiden terpilih (Joko Widodo-Ma'ruf Amin), PKS tetap mengambil posisi sebagai "oposisi" guna menjaga kesehatan demokrasi (CNN Indonesia, 2019). Pada Februari 2020 kemarin misalnya, Anggota Komisi X DPR Fraksi PKS, Ledia Hanifa Amaliah, mengkritisi koordinasi antara Kementerian/Lembaga (K/L) di era pemerintahan periode kedua Jokowi yang masih berkutat dalam masalah koordinasi, khususnya perihal pembangunan gedung Kemendikbud di Jakarta (Burhan, 2020). Kemudian, kritik tajam dan terang- 
terangan juga dilontarkan para politikus di era pandemi Covid-19. Salah satu contohnya, Mardani Ali Sera selaku Ketua DPP PKS, mengkritisi wacana kucuran dana Rp. 72 Miliar yang dialokasikan untuk influencer guna menampik dampak Corona terhadap sektor pariwisata (CNN Indonesia, 2020). Atau, berita terbaru di akhir April 2020 kemarin, Sukamta yang menjabat sebagai Wakil Ketua Fraksi PKS DPR RI mengkritisi pemerintah pusat atas kedatangan 500 tenaga kerja asing (TKA) asal China ke Sulawesi Utara yang hendak dipekerjakan di PT Virtue Dragon Nickel Industry (VDNI) (Candraditya, 2020). Oleh karena itu, PKS belum cukup memenuhi prasyarat sebagai partai yang berafiliasi dengan pemerintah dan disebut sebagai partai kartel.

\section{ORGANISASI KOLATERAL: MEKANISME BERTAHAN ATAU STRATEGI ABADI?}

Organisasi kolateral dimaknai sebagai lembaga yang sudahsecaratradisionalterlembaga, disusun berdasarkan hierarki, dipimpin oleh elit yang stabil, dan mampu menjamin hubungan pertukaran yang stabil dengan partai politik (Biezen \& Kopecky, 2014). Organisasi tersebut memiliki peran sebagai mediator antara elit partai dengan massa publik. Organisasi kolateral secara garis besar dibagi menjadi dua tipe, yakni organisasi 
sayap dan organsisasi massa. Istilah organisasi sayap merujuk pada kelompok yang memiliki kepentingan tumpang tindih satu sama lainnya sedangkan organisasi massa merupakan kelompok independen dari partai politik dan memiliki nilai negosiasi yang tinggi. Dalam praktiknya, organisasi kolateral kerap kali dijadikan sebagai cara alternatif perolehan suara apabila anggota resmi partai mengalami kemerosotan.

Organisasi kolateral dalam hal ini dijelaskan dalam logika political linkage antara partai politik dan organisasi afiliasi yang menggantikan peran anggota partai (Hooghe \& Ko "lln, 2018). Terdapat tiga dimensi kesetaraan antara organisasi afiliasi dengan anggota resmi partai politik yang melingkupi cara kerja organisasi afiliasi dengan partai politik. Pertama, organisasi afiliasi partai memiliki peran dalam menjaga stabilitas dukungan terhadap partai politik meski stabilitas yang dihasilkan oleh anggota partai lebih tinggi dibandingkan stabilitas yang dihasilkan organisasi afiliasi partai. Kedua adalah kesamaan sikap politik. Kesetaraan yang terjalin antara pendukung loyal dengan anggota partai dalam hal ini diraih melalui kesetaraan komitmen dan ideologi atas partai politik. Kemudian, kondisi ketiga, kesamaan dalam perilaku politik. Dimensi ini menunjukkan bahwa pendukung loyal dan anggota 
partai dapat setara dalam hal keaktifan dalam kegiatan partai dan kampanye serta dalam hal stabilias preferensi partai.

Ditilik berdasar sejarah pembentukan partai PKS, organisasi kolateral merupakan hal yang tidak bisa dilepaskan darinya. Sejak awal PK berdiri, Jemaah Tarbiyah, sebagai organisasi pembentuk sekaligus organsisasi sayap partai, merupakan satu kesatuan dengan PK. Semua anggota Jemaah Tarbiyah secara otomatis menjadi anggota PK. Selain itu, semua kegiatan dan pelatihan keagamaan dilakukan oleh PK. Sementara itu, pemimpin dari Jemaah Tarbiyah diakomodasi dalam institusi majelis syura dan semua anggota Jemaah Tarbiyah harus memilih PK (Machmudi, 2006).

Organisasi kolateral yang sifatnya lebih pada organisasi massa ditunjukkan dengan adanya hubungan independen antara PKS dengan KAMMI (Kesatuan Aksi Mahasiswa Muslim Indonesia). KAMMI sebagai organisasi yang mayoritas berisi kelompok Tarbiyah sering kali diterka sebagai organisasi penyedia stok kader bagi PKS. Namun, skripsi yang ditulis oleh Fatra Yudha Pratama (2019) menunjukkan bahwa pola hubungan antara KAMMI dan PKS bersifat independen. Artinya, keanggotaan KAMMI tidak terintegrasi dengan PKS. Selain itu, hak anggota antara KAMMI dan PKS diatur 
oleh organisasi masing-masing. Karena hubungannya yang bersifat dua arah informal sehingga tidak ada intervensi besar dan mengikat terhadap KAMMI. Pengaruh KAMMI terhadap PKS akan selalu bergantung pada tiap isu dan individu. Yakni, meskipun banyak alumni KAMMI merupakan anggota PKS, tetapi tidak serta merta ada kaitan institusional antara keduanya.

PKS memang menggandeng Jemaah Tarbiyah yang mayoritas anak muda sebagai basis massa dan sekaligus organisasi kolateralnya. Strategi awal yang dikelola oleh Jemaah Tarbiyah dalam proses Islamisasi adalah strategi individu. Penganut baru harus siap untuk memutus hubungan dengan masyarakat atau kelompok lama mereka. Jadi, yang diprioritaskan adalah komitmen terhadap doktrin baru. Mereka berpanduan bahwa Islam adalah satu-satunya petunjuk hidup (minhaj al-hayah) (Machmudi, 2006). Dengan demikian, kuatnya ikatan doktrin membuat Jemaah Tarbiyah dapat menjadi agen komunikasi politik yang sangat tepat guna menyebarkan identitas ke-Isalaman PKS. Kemudian, para kader dan aktivis PKS harus memublikasikan perbuatan baik PKS dalam rangka menyosialisasikan dan mengiklankan reputasi partai (Pratama, 2019). Selain itu, strategi yang digunakan ialah mendorong kader-kadernya untuk memiliki 
banyak anak (Nurdin, 2011). Kikue Hamayotsu (2011) menilai bahwa PKS sukses dalam merekrut komitmen pemuda Muslim. Yang mana-menurutnya-disebabkan karena dua faktor, 1) rekrutmen dan promosi kader berdasakan pernikahan. Yakni, menawarkan kepada pemuda terkait ambisi dan keimanan serta peluang karir politik dan menjadikan hal tersebut sebagai alasan komitmen pada kepentingan kolektif partai.; 2) waktu ekspansi organisasi yang bertepatan dengan rekruitmen pejabat publik di level lokal.

\section{KINERJA ELEKTORAL}

Dalam beberapa pemilu terakhir, PKS hampir selalu tampil menawan dengan perolehan suaranya. Pada pemilu pertamanya tahun 1999, PK mendapat suara sebesar 1.436 .565 atau sebesar $1,36 \%$ dari total perolehan suara nasional dan menduduki 7 kursi dengan stembus accord. Kemudian, pada pemilu tahun 2004 PKS berhasil meraih 8.149.457 suara atau sebanyak $7,20 \%$ dari total perolehan suara nasional. Ia berhasil mendudukkan 45 wakilnya di DPR RI. Pada pemilu tahun 2009, PKS meraih jumlah pemilih dengan angka 8.204.946 suara. Dari segi presentase, ia juga naik ke angka $7,89 \%$ dari total suara nasional, serta dapat menduduki sebanyak 57 kursi. Saat pemilu 2014, PKS 
kembali mengalami kenaikan jumlah pemilih menjadi 8.480.204 suara. Namun, presentase suara sah nasional menurun ke angka 6,79\%, serta harus kehilangan 17 kursi di DPR dan menyisakan 40 kursi. Terakhir, yakni pada pemilu tahun 2019, suara PKS melejit pesat ke angka 11.493.663 atau sekitar 8,21\% suara sah nasional (Komisi Pemilihan Umum, 2010; Ihsanuddin, 2018; Farisa, 2019). Dengan angka yang cenderung naik dari tahun ke tahunnya, PKS terbukti tetap mampu meningkatkan perolehan suaranya pada tiap pemilu yang ia ikuti.

\section{Perolehan Suara Pileg PKS}

Total Suara

14.000 .000

12.000 .000

10.000 .000

8.000 .000

6.000 .000

4.000 .000

2.000 .000

0
1.436 .565

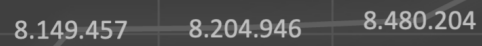




\section{Perolehan Suara Pileg PKS}

\section{Dalam \%}

9,00

8,00

7,89

\section{ORGANISASI KOLATERAL: BUKAN MEKANISME BERTAHAN?}

Fenomena kemerosotan jumlah anggota beberapa partai di Eropa yang dikemukakan oleh Biezen dan Poguntke (2014) serta didukung oleh Ko “lln (2016) juga terjadi di dalam tubuh PKS. Kenaikan melejit terjadi pada tahun 1999 ke tahun 2004 merupakan hasil kinerjanya yang mempromosikan kampanye "bersih dan peduli” serta memaksimalkan komunikasi politik melalui kader-kader serta aktivis Jemaah Tarbiyah. Sementara itu, apabila merujuk pada Biezen dan Poguntke (2014) yang menerangkan bahwa penurunan 
anggota partai dapat dilacak dari sisi perubahan bentuk partai dari massa ke catch-all bahkan kartel, fenomena perubahan bentuk partai juga terjadi di tubuh PKS.

Merujuk pada Lobo (2008), sekiranya cukup tepat apabila mengandaikan Jemaah Tarbiyah sebagai kelompok yang masuk dalam pembilahan sosial yang ingin diwakili dalam politik guna menyuarakan misi kelompoknya. Partai Keadilan (PK)-sebagai bibit dari PKS-dibentuk melalui mekanisme massa dengan basis Jemaah Tarbiyah. Dengan demikian, PKS di masa awal keberadaannya menjadi sangat ideologis walaupun secara perilaku politik terkesan membuka diri. Seiring berjalannya waktu, PKS mencerminkan usaha mobilisasi suara dibanding mempromosikan ideologi partai. Hingga pada suatu titik, yakni PKS benar-benar menyatakan telah membuka diri terhadap non-Muslim dalam partainya dan menegaskan adanya perilaku dominan catch-all yang ditampilkan pada publik. Namun, ia di sisi lain, tetap menjalin dukungan Islam konservatif serta dalam beberapa isu yang menyinggung mengenai kepercayaan mayoritas anggotanya, PKS akan secara terang-terangan menampilkan wajah eksklusivitas Islamisnya. Namun, PKS belum dapat dikatakan sebagai partai kartel. Karena, pada faktanya ia adalah salah satu partai yang tak bergabung ke dalam koalisi formasi 
kabinet presiden terpilih 2019 lalu, serta secara gencar mengkritisi jalannya pemerintahan. Dengan demikian, premis ketergantungan tidak dapat dibuktikan dalam hubungan PKS dan negara sehingga benarlah istilah "partai radikal, dengan kata lain, mungkin belum tentu menjadi lebih moderat secara ideologis, tetapi akan menyesuaikan perilaku mereka sesuai dengan insentif kelembagaan" (Kalyvass, 2000; Share and Mainwaring, 1986: 175 dalam Buehler, 2012).

Perubahan bentuk partai dan penurunan anggota dapat dikonfirmasi secara bersamaan dalam tubuh PKS. Namun, hal tersebut sama sekali tidak memengaruhi performa PKS dalam pemilihan legislatif di Indonesia. Bahkan, justru menunjukkan adanya kinerja gemilang dari perolehan suara tahun per tahunnya. Berkaca pada Biezen dan Poguntke (2014) yang berargumen bahwa organisasi kolateral sebagai mekanisme pengganti peran anggota, PKS juga melakukan hal serupa dalam proses mobilisasi pemilih. Pertama, Jemaah Tarbiyah yang membawahi kelompok-kelompok kecil di kampus dan sekolah-sekolah menjadi organisasi sayap partai PKS dan sekaligus menjadi basis anggota. Dengan demikian, tidak serta merta dapat disebut sebagai organisasi kolateral karena memang Jemaah Tarbiyah merupakan organ pembentuk PKS. 
Selanjutnya, yakni organisasi kolateral independen KAMMI (Kesatuan Aksi Mahasiswa Muslim Indonesia) yang memiliki basis di kampus-kampus. Secara organisasional hubungan keduanya tampak informal. Namun, secara personal antara KAMMI dan PKS memiliki hubungan yang cenderung dekat dan saling memengaruhi. Keterlibatan organisasi kolateral di dalam strategi kampanye PKS bukan merupakan fenomena baru. Bahkan, dapat dikatakan bahwa PKS memang terbentuk dari organisasi kolateral. Dewasa ini, walaupun PKS berorientasi mencari suara sebanyak-banyaknya, tetapi solidaritas dan loyalitas yang sudah menjadi kultur dalam massa dan anggota PKS membuatnya tak harus mengorbankan ambisi pencarian suara demi mengonsolidasikan anggota. Fakta-fakta lekatnya ideologi dan komitmen serupa yang dimiliki organisai kolateral dengan partai politik membuatnya dalam ualsan ini terkonfirmasi memiliki kesamaan dalam sikap dan tindakan politik. Di sisi lain, organisasi kolateral juga telah berhasil menjaga stabilitas perolehan suara PKS, baik dilakukan secara langsung maupun tidak.

Pada titik ini, artikel jurnal "The Decline of Membership-Based Politics" (Biezen \& Poguntke, 2014) secara gamblang mampu menjelaskan penyebab 
menurunnya anggota partai PKS dan mekanisme bertahannya. Namun, artikel tersebut tidak serta merta dapat menerangkan fenomena riil yang terjadi di PKS mengenai organisasi kolateral. Pelibatan organisasi kolateral dalam strategi kampanye PKS sudah dijalankan bahkan sebelum ada isu penurunan jumlah anggota. Oleh karenanya, organisasi kolateral bukanlah mekanisme bertahan bagi PKS melainkan suatu strategi "abadi" yang disandingkan di sisi loyalitas anggota partai. Walaupun anggota partai kian menyurut, tetapi jaringan serta kuatnya kultur doktrinasi yang dimilikinya membuat PKS memiliki basis suara yang cukup stabil dalam ajang pemilihan legistalif dari tahun ke tahun. Seperti yang dikatakan oleh Hooghe \& Kölln (2018), hanya pendukung setia yang akan selalu dapat dipastikan dukungannya. Bagaimanapun, dalam komitmen aktivisme politik, member partai memiliki peran yang lebih tinggi dibandingkan dengan supporter. Keanggotaan formal adalah yang paling dapat menjamin aktivisme politik. Dalam kasus ini, PKS mencerminkan adanya upaya sinkronisasi antara anggota dan pendukung (organisasi kolateral) guna mencapai perolehan suara yang gemilang. 


\section{KESIMPULAN DAN REFLEKSI}

Di beberapa partai politik Eropa, muncul suatu fenomena penurunan anggota partai politik yang cukup signifikan. Salah satu cara menelisisk penyebab menurunnya anggota partai-partai tersebut ialah dengan menelaah perubahan bentuk partai dari massa ke catch-all bahkan kartel. Semakin suatu partai berorientasi pada peraihan suara di pemilihan legislatif, maka akan semakin terjadi penurunan anggota formal yang dimilikinya. Oleh karenanya, diperlukan adanya organisasi sayap atau organisasi massa independen sebagai kelompok penyambung komunikasi antara elit partai dan massa. Organisasi tersebut biasa disebut sebagai organisasi kolateral. Tugasnya untuk menggantikan peran anggota formal yang hilang dalam rangka pencapaian suara pemilihan.

Fenomena hampir serupa juga berlaku dalam tubuh PKS. Sebagai partai yang dibangun atas mekanisme massa, PKS hadir di sistem demokrasi Indonesia sebagai partai berideologi Islam revivalis karena berbasis Jemaah Tarbiyah. Dengan kuatnya doktrin terhadap misi Islamisasi struktur sosial politik, PKS masa awal sangat menjunjung tinggi ideologinya. Seiring berjalannya waktu, PKS mulai memoderasi diri di sisi perilaku politik dalam rangka mobilisasi suara. 
Ia mulai membuka diri bagi non-Muslim dan dengan tetap menjalin hubungan baik bersama kelompok Islam konservatif. Oleh karenanya, walaupun dinilai sudah mencapai taraf catch-all, PKS tetap menampilkan wajah eksklusivitasnya ketika membahas isu-isu yang bersinggungan dengan keyakinan kelompok Jemaah Tarbiyah. Dalam rangka perubahan bentuk partai, PKS hanya "berhenti" pada taraf catch-all, belum sampai pada titik kartel. Karena, ia tidak menunjukkan adanya hubungan yang menyatu dengan negara.

Dari pergeseran bentuk partai yang terjadi, PKS juga dikonfirmasi mengalami penurunan anggota partai. Namun, itu tidak memengaruhi kinerja pemilihan legislatifnya yang cenderung menawan. Hal ini bukan karena semata mengalihkan tanggung jawab kampanye pada organisasi kolateral seperti yang dikatakan oleh Biezen dan Poguntke (2014). PKS dalam strateginya tetap menjalin hubungan dengan anggota partai dan di satu sisi, ia menjalin hubungan dengan organisasi kolateral. Walaupun pada akhirnya, organisasi tersebut hampir serupa secara identitas dengan anggota partai. Para anggota partai politik yang berdasar solidaritas yang kuat, jaringan yang luas di kampus dan sekolahsekolah, serta basis doktrinasi yang dalam menjadikan modal utama dalam keberhasilan kampanye PKS dari 
tahun ke tahun-di samping memanfaatkan organisasi kolateral. Bagaimanapun, dalam komitmen aktivisme politik, member partai memiliki peran yang lebih tinggi dibandingkan dengan supporter. Keanggotaan formal adalah yang paling dapat menjamin aktivisme politik (Hooghe \& Ko "lln, 2018).

\section{ACKNOWLEDGEMENT}

Penulis menyampaikan rasa terima kasih kepada segenap pihak yang membantu penulis dalam proses penyusunan hingga terbitnya artikel jurnal ini.

\section{AFILIASI LEMBAGA DAN PEMBIAYAAN}

Meski studi ini bermula dari penugasan mata kuliah Pengorganisasian Partai Politik di Departemen Politik dan Pemerintahan UGM, penelitian ini dibiayai secara mandiri oleh penulis. 


\section{DAFTAR PUSTAKA}

Biezen, I. v., \& Kopecky, P. (2014). The cartel party and the state: Party-state linkages in European democracies. Party Politics, 20(2), 170-182.

Biezen, I. v., \& Poguntke, T. (2014). The Decline of Membership-Based Politics. Party Politics, 2O(2), 205-216. doi:10.1177/1354068813519969

Boucek, F. (2009). RETHINKING FACTIONALISM; Typologies, Intra-Party Dynamics and Three Faces of Factionalism. Party Politics, 15(4), 455-485.

Buehler, M. (2012). Revisiting the inclusion-moderation thesis in the context of decentralized institution; The behavior of Indonesia's Prosperous Justice Party in national and local politics. Party Politics, 19(2), 210229.

Febriyanty, Yenny, Ghafur, Jamaludin, \& Ariyanto. (2019). Peran Organisasi Sayap Partai Politik (OSP) dalam Mencegah Kemerosotan Keanggotaan Partai Politik di Indonesia. Artikel Simposium.

Fionna, U., \& Tomsa, D. (2020). Changing Patterns of Factionalism in Indonesia: From Principle to Patronage. Journal of Current Southeast Asian Affairs, 1-20. 
Hamayotsu, K. (2011). Beyond Faith and Identity: mobilizing Islamic youth in democratic Indonesia. The Pacific Review, 24(2), 225-247.

Hasan, N. (2009). Islamist Party, Electoral Politics and Da'wa Mobilization among Youth: The Prosperous Justice Party (PKS) in Indonesia. RSIS Working Paper, i - 27.

Hooghe, M., \& Kölln, A.-K. (2018). Types of party affiliation and the multi-speed party: What kind of party support is functionally equivalent to party membership? Party Politics, 1-11.

Kölln, A.-K. (2016). Party membership in Europe: Testing party-level explanations of decline. Party Polititics, 22(4), 465-477.

Komisi Pemilihan Umum. (2010). Modul I Pemilih Untuk Pemula. Jakarta: KPU.

Lobo, M. C. (2008). Parties and Leaders Effects: Impact of Leader in the Vote for Different Types. Party Politics, 14(3).

Machmudi, Y. (2006). Islamising Indonesia: the rise of Jemaah Tarbiyah and the Prospereous Justice Party (PKS). Canberra: ANU E Press. 
Munabari, F. (2017). Reconciling sharia with "Negara Kesatuan Republik Indonesia”: The ideology and framing strategies of the Indonesian Forum of Islamic Society. International Area Studies Review, $20(3), 242-263$.

Nurdin, A. A. (2011). PKS' Demokratic Experiences in Recruiting Members and Leaders. Al-Jami'ah, 49(2), 329-360.

Permata, A.-N. (2008). Islamist Party and Democratic Participation: Prosperous Justice Party (PKS) in Indonesia 1998-2006. Université de Münster: Disertasi.

Poguntke, T. (2002). Parties Without Firm Social Roots? Party Organisational Linkage . Working Paper 13 Keele European Parties Research Unit (KEPRU).

Pratama, F. Y. (2019). Pola elasi KAMMI Sebagai Organisasi Kolateral PKS Pasca Konflik dan Fahri Hamzah. Skripi. Yogyakarta: Departemen Politik dan Pemerintahan Fisipol UGM.

Priohutomo, H. W., Kamarudin, \& Hidayat, S. (2019). The Emergence of Gerakan Arah Baru Indonesia (Garbi) and Factionalism in Partai Keadilan Sejahtera (PKS). Jurnal Politik, 5(1), 29-64. 
Rahmat, M. I. (2008). Ideologi Politik PKS; Dari Masjid Kampus ke Gedung Parlemen. LKIS Pelangi Aksara.

Tanuwidjaya, S. (2012). PKS in post-Reformasi Indonesia; Catching the catch-all and moderation wave. South East Asia Research, 20(4), 533-549.

Tomsa, D. (2012). Moderating Islamism in Indonesia: Tracing Patterns of Party Change in the Prosperous Justice Party. Political Research Quarterly, 65(3), 486-498.

\section{WAWANCARA}

Arfian. (2019). Jumlah Anggota PKS.

\section{ARTIKEL ONLINE}

Aspinall, E., Fossati, D., Muhtadi, B., \& Wrburton, E. (2018). Mapping the Indonesian political spectrum. Diakses dari New Mandala: https://www.newmandala.org/ mapping-indonesian-political-spectrum/ 
Burhan, F. A. (2020). PKS Kritik Koordinasi Pemerintahan Jokowi di Periode Dua Masih Buruk. Diakses dari Katadata: https://www.google.com/amp/s/ katadata.co.id/amp/berita/2020/o2/17/pks-kritikkoordinasi-pemerintah-jokowi-di-periode-duamasih-buruk

Candraditya, V. J. (2020). Politikus PKS Kitik Pemerintah Pusat Izinkan 500 Warga China Masuk Sulut di Tengah Wabah Corona. Diakses dari Tribunnews: https://www.google.com/amp/s/m.tribunnews. com/amp/nasional/2020/o4/30/politikus-pkskritik-pemerintah-pusat-izinkan-500-warga-chinamasuk-sulut-di-tengah-wabah-corona

CNN Indonesia. (2019). Istikamah PKS di Oposisi Jokowi dan Upaya Cicil Dukungan 2024. Diakses dari CNN Indonesia: https://m.cnnindonesia. com/nasional/20191016193636-32-440127/ istikamah-pks-di-oposisi-jokowi-dan-upaya-cicildukungan-2024

CNN Indonesia. (2020). PKS Kritik Anggaran buat Influencer Redam Dampak Corona. Diakses dari CNN Indonesia: https://m.cnnindonesia.com/ nasional/20200226163030-32-478388/pks-kritikanggaran-buat-influencer-redam-dampak-corona 
Farisa, F. C. (2019). Hasil Lengkap Perolehan Kursi DPR 2019-2024. Diakses dari Kompas.com: https:// nasional.kompas.com/read/2019/o8/31/11152361/ hasil-lengkap-perolehan-kursi-d pr-20192024? page $=2$

Ihsanuddin.(2018).PKS,PartaiKaderyang TakTergantung pada Satu Sosok. Diakses dari Kompas.com: https:// nasional.kompas.com/read/2018/02/22/07511951/ pks-partai-kader-yang-tak-tergantung-pada-satusosok

Kompas.com. (2008). Mukernas Bali Penegasan PKS membuka Diri. Diakses dari Kompas: https://www. google.com/amp/s/amp.kompas.com/nasional/ $\mathrm{read} / 2008 / 02 / 01 / 19064654 / \mathrm{mukernas}$. bali. penegasan.pks.membuka.diri.

Reinjani,D.(2018).SMRC: LoyalitasMasyarakatIndonesia terhadap Partai Terendah di Dunia. Diakses dari kbr.id: https://kbr.id/nasional/o1-2018/smrc loyalitas_masyarakat_indonesia_terhadap_partai_ terendah_di_dunia/94269.html

Salabi, A. (2021). Party ID Rendah, Pemilh Merasa Lebih Terwakili oleh Anggota DPR, Bukan Partai. Diakses dari rumahpemilu.org: https://rumahpemilu.org/ party-id-rendah/ 